\title{
Perception and practices pertaining to menstruation among adolescent girls
}

\author{
Mekle D. ${ }^{1}$, Rathore R. ${ }^{2 *}$, Dixit J. ${ }^{3}$, Kapoor A. ${ }^{4}$ \\ DOI: https://doi.org/10.17511/ijpr.2020.i03.06 \\ 1 Dinesh Mekle, Associate Professor, Department of Pediatrics, People's College of Medical Science and Research Centre, Bhopal, Madhya \\ Pradesh, India. \\ ${ }^{2 *}$ Richa Rathore, PG Resident 3rd year, Department of Pediatrics, People's College of Medical Science and Research Centre, Bhopal, Madhya \\ Pradesh, India. \\ 3 Jagdamba Dixit, Professor and HOD, Department of Pediatrics, People's College of Medical Science and Research Centre, Bhopal, Madhya \\ Pradesh, India. \\ ${ }^{4}$ Anju Kapoor, Professor, Department of Pediatrics, People's College of Medical Science and Research Centre, Bhopal, Madhya Pradesh, \\ India.
}

Objective: To assess the perceptions and practices related to menstruation among adolescent girls of rural and urban schools. Methodology: This was a cross-sectional study conducted at selected government as well as private schools of rural and urban areas. Adolescent girls of age group between 10-17 years who have attained menarche were enrolled in the study. Data regarding sociodemographic profile, knowledge, practices, and perception related to menstruation was obtained using a predefined questionnaire. Results: The study enrolled 350 girls from rural and 350 girls from urban schools. Maternal education was found to be higher in an urban setting as compared to the rural setting. Genital hygiene practices and usage of the sanitary pad were significantly better amongst urban girls as compared to rural girls $(p<0.01)$. About $35 \%$ of girls in the urban setting and $26 \%$ of rural settings were mentally prepared for menarche. Most of the girls were forced to follow various types of restrictions like going to the temple, entering into the kitchen, etc during menstruation in both the settings. Conclusion: There is poor mental preparedness for menstruation before attaining menarche, poor hygienic practices, and negative perception regarding menstruation among adolescent girls. This requires educational intervention involving both young girls and their mothers.

Keywords: Adolescent girl, Hygienic practices, Menstruation

Corresponding Author

Richa Rathore, PG Resident 3rd year, Department of Pediatrics, People's College of Medical Science and Research Centre, Bhopal, Madhya Pradesh, India. Email: rics1507@gmail.com
How to Cite this Article

Mekle D, Rathore R, Dixit J, Kapoor A. Perception and practices pertaining to menstruation among adolescent girls. Pediatric Rev Int J Pediatr Res. 2020;7(3): 146-151.

Available From

https://pediatrics.medresearch.in/index.php/ijpr/arti cle/view/581
To Browse

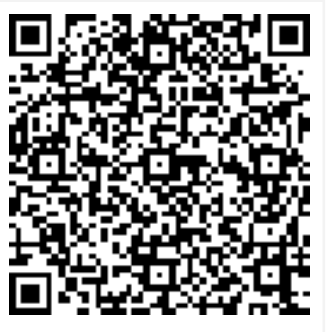

Manuscript Received 2020-03-06

Conflict of Interest No

Review Round 1
2020-03-16
Funding
Nil

Review Round 1

$\mathrm{Nil}$

Review Round 2
2020-03-21
$\begin{gathered}\text { Ethical Approval } \\ \text { Yes }\end{gathered}$

Review Round 2

Yes
Review Round 3

Accepted 2020-03-28

Plagiarism X-checker $4 \%$

(c) 2020 by Dinesh Mekle, Richa Rathore, Jagdamba Dixit, Anju Kapoor and Published by Siddharth Health Research and Social Welfare Society. This is an Open Access article licensed under a Creative Commons Attribution 4.0 International License https://creativecommons.org/licenses/by/4.0/ unported [CC BY 4.0]. 


\section{Introduction}

The WHO has defined adolescence as a distinct phase of life and comprises of individuals between 10 and 19 years of age [1].The adolescent period in females has been marked by the onset of menarche [2]. These girls may face many premenstrual problems like acne, tender breasts, bloating, feeling tired, irritability, and mood changes. They can be severe in 3 to $8 \%$ of females [3].

In India, various myths and superstitions have long been associated with menstruation. Even mentioning the topic of menstruation has been a taboo in the past and even today [4]. Hygienic practices during menstruation are essential as poor menstrual hygiene is associated with increased vulnerability to reproductive tract infections (RTI) [5]. Thus, girls should be educated about the proper hygienic practices as well as bring them out of traditional beliefs, misconceptions, and restrictions regarding menstruation [6]. Women who practice menstrual hygiene are less vulnerable to RTI and its consequences. Therefore, imparting knowledge about menstruation from the early adolescent period may turn into practice and persist throughout life $[7,8]$.

Menstrual hygiene is rarely discussed at home or in schools. The problem is prevalent in both rural as well as in urban areas but more so in rural and poorly educated families. The present study is conducted to assess the perceptions as well as practices related to menstruation among adolescent girls of rural and urban schools and to find out the differences in these two groups.

\section{Objectives}

- To find out the perception and practices regarding menstruation amongst adolescent girls in rural and urban schools

- To find out the difference between these two groups.

\section{Methodology}

The present cross-sectional study was conducted over a period of 1 and a half years from 1st January 2018 to 30th July 2019 at selected government and private schools of the rural and urban areas as per WHO [9]. All the adolescent girls in the age group of 10-19 years who had attained menarche were included in the study. Girls who did not give consent were excluded from the study.
Late adolescents (18-19 years of age) were automatically excluded as they are out to colleges by this age.

After obtaining ethical clearance from the Institutional Ethics Committee, permission from the principals of selected schools was obtained. The nature and purpose of the study were explained to all the study participants and their verbal consent was taken. Subsequently, they were given a questionnaire and were asked to fill it in the school itself. All doubts were cleared by PI then and there only. The questionnaire was designed to obtain detailed demographic data such as present age, age at menarche, education, details of menstrual cycles and maternal literacy, etc. What hygienic practices they are following were also asked. A five-point Likert scale was used to assess their perception of the issue.

Statistical analysis: Data was compiled using Ms Excel and analyzed using SPSS 20 software. Percentage and mean were calculated. A Chi-square test was applied to study the association.

\section{Results}

Overall, 700 adolescent girls responded to the questionnaire, covering rural and urban areas in a $1: 1$ ratio. The demographic characteristics of the participants are shown in Table 1. Mothers from rural areas are found to be less educated as compared to mothers of the urban area through the difference in the working status of mother's of both the groups was not significant. The detail of the menstrual cycle is given in Table 2 . The majority of the girls of both rural (60.6\%) and urban (56.9\%) settings attained Menarche at the age of $12-14$ years.

About $63.7 \%$ of girls from urban areas used soap and water to clean their private parts as compared to $48.9 \%$ in the rural area (Table 3 ). The use of sanitary pad is much higher $96.3 \%$ in the urban area as compared to $69.4 \%$ in the rural area. Girls from urban schools were more comfortable in changing the pads at school as compared to rural schools, though the overall percentage was very low. Many types of restrictions were posed on menstruating girls like going to temples and schools in both the rural and urban areas (Figure 1). Other restrictions like social interaction, using separate clothes, not eating certain types of foods like papaya or drinking milk, etc were slightly more in a rural setting. 
Attitude, perception of girls regarding menstruation are shown (in table 4). It was found that the majority of the girls were not ready when they got their first periods. Very few participants from both settings were not aware of how to respond to their first period. Knowledge regarding the physical changes taking place during menstruation was more among the urban area as compared to the rural setting.

Table-1: Demographic characteristics.

\begin{tabular}{|c|c|c|c|c|}
\hline & Urban (\%) & ) Rural (\%) & $\mid$ Total $(\%) \mid$ & P-value \\
\hline \multicolumn{5}{|l|}{ Age } \\
\hline 10-13 (Early adolescence) & $73(20.9)$ & $46(13.1)$ & $119(17.0)$ & \multirow[t]{2}{*}{0.007} \\
\hline 14-17 (Middle adolescence) & $277(79.1)$ & 304 (86.9) & $581(83.0)$ & \\
\hline \multicolumn{5}{|l|}{ Class } \\
\hline 6-8th standard & 115 (32.9) & $119(34)$ & $234(33.4)$ & \multirow[t]{2}{*}{0.749} \\
\hline 9-12th standard & $235(67.1)$ & $231(66)$ & $466(66.6)$ & \\
\hline \multicolumn{5}{|l|}{ Education status of the mother } \\
\hline Illiterate & $48(13.7)$ & $125(35.7)$ & $173(24.7)$ & \multirow[t]{6}{*}{0.001} \\
\hline Primary & $98(28.0)$ & $146(41.7)$ & $244(34.8)$ & \\
\hline Secondary & $104(29.7)$ & $68(19.4)$ & $172(24.5)$ & \\
\hline Higher secondary & $54(15.4)$ & $9(2.6)$ & $63(9)$ & \\
\hline Graduate & $38(10.9)$ & $2(0.6)$ & $40(5.9)$ & \\
\hline Post graduate & $8(2.3)$ & $0(0)$ & $8(1.1)$ & \\
\hline \multicolumn{5}{|l|}{ Working status of the mother } \\
\hline Working & $112(32.0)$ & $104(29.7)$ & 216 (30.9) & \multirow[t]{2}{*}{0.497} \\
\hline Not working & $238(68)$ & $246(70.3)$ & $484(68.1)$ & \\
\hline
\end{tabular}

Table-2:- Details of menstrual cycles.

\begin{tabular}{|c|c|c|c|c|}
\hline & Urban (\%) & Rural (\%) & Total (\%) & P-value \\
\hline \multicolumn{5}{|c|}{ Age at which menarche was attained } \\
\hline $10-11$ & $133(38)$ & $115(32.9)$ & $248(35.4)$ & \multirow[t]{3}{*}{0.001} \\
\hline $12-14$ & $212(60.6)$ & 199(56.9) & 411 (58.7) & \\
\hline$>14$ & $5(1.4)$ & $36(10.2)$ & $41(5.9)$ & \\
\hline \multicolumn{5}{|c|}{ Regularity of cycles } \\
\hline Regular & $221(63.1)$ & 202 (57.7) & $423(60.4)$ & \multirow[t]{2}{*}{0.220} \\
\hline Irregular & $129(36.9)$ & $148(42.3)$ & $277(39.6)$ & \\
\hline
\end{tabular}

\begin{tabular}{|c|c|c|c|c|}
\hline$<3$ day & $102(29.1)$ & $92(26.2)$ & $194(27.7)$ & \multirow[t]{3}{*}{0.178} \\
\hline$(3-5)$ day & 167 (47.7) & 191 (54.6) & 358 (51.1) & \\
\hline$>5$ day & $81(23.2)$ & $67(19.2)$ & $148(21.2)$ & \\
\hline \multicolumn{5}{|c|}{ The interval between two cycles } \\
\hline$<21$ days & 84 & 84 & 168 & \multirow[t]{2}{*}{0.733} \\
\hline 21-28days & 200 & 192 & 392 & \\
\hline
\end{tabular}

Table-3:- Hygiene practices followed by the girls.

\begin{tabular}{|c|c|c|c|c|}
\hline & Urban (\%) & Rural (\%) & Total $(\%)$ & P-value \\
\hline \multicolumn{5}{|c|}{ Washing of genitalia during menstruation } \\
\hline Only with water & $64(18.3)$ & $169(48.3)$ & $233(33.3)$ & \multirow[t]{3}{*}{0.001} \\
\hline With soap and water both & $223(63.7)$ & $171(48.9)$ & $394(56.3)$ & \\
\hline Water and Antiseptic & $63(18)$ & $10(2.8)$ & $73(10.4)$ & \\
\hline \multicolumn{5}{|l|}{ Absorbent material used } \\
\hline Sanitary pads & $337(96.3)$ & $243(69.4)$ & $580(82.8)$ & \multirow[t]{3}{*}{0.001} \\
\hline Homemade cloth pads & $5(1.4)$ & $27(7.7)$ & $32(4.6)$ & \\
\hline Both & $8(2.3)$ & $80(22.9)$ & $88(12.6)$ & \\
\hline \multicolumn{5}{|c|}{ Number of pads used per day } \\
\hline $1-2$ & $88(25.1)$ & $82(23.4)$ & $170(24.3)$ & \multirow{3}{*}{0.868} \\
\hline $3-4$ & $188(53.7)$ & $193(55.1)$ & $381(54.4)$ & \\
\hline$>4$ & $74(21.2)$ & 75 (21.5) & $149(21.3)$ & \\
\hline \multicolumn{5}{|c|}{ Are they comfortable changing pad at school } \\
\hline Yes & $83(23.7)$ & $37(10.6)$ & $120(17.1)$ & \multirow[t]{2}{*}{0.002} \\
\hline No & $267(76.3)$ & $313(89.4)$ & $580(82.9)$ & \\
\hline
\end{tabular}

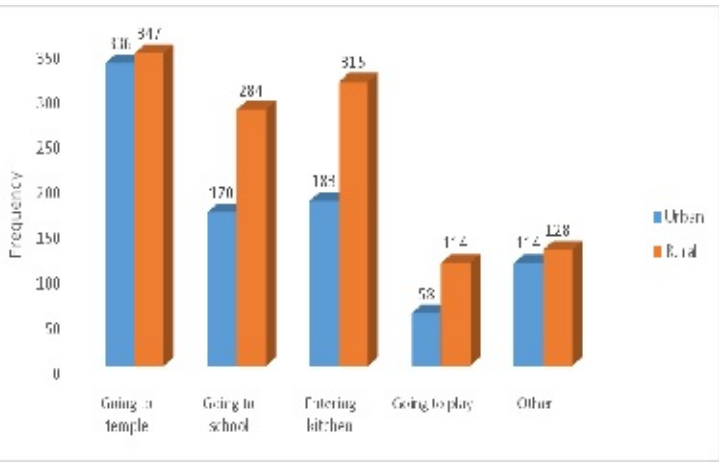

Fig-1: Restrictions posed on menstruating girls.

Table-4: Attitude and perception of girls regarding menstruation.

\begin{tabular}{|c|c|c|c|c|c|c|c|c|}
\hline Question & Group & $\begin{array}{l}1 \text { Strongly } \\
\text { Disagree }\end{array}$ & 2 Disagree & 3 Neutral & $\begin{array}{c}4 \\
\text { Agree }\end{array}$ & $\left|\begin{array}{c}5 \text { Strongly } \\
\text { Agree }\end{array}\right|$ & Total & $\begin{array}{c}\text { Chi-square value } \\
\text { P-value }\end{array}$ \\
\hline \multirow[t]{2}{*}{$\begin{array}{l}\text { I was given helpful information about periods } \\
\text { before I got my first one }\end{array}$} & Urban & $82(23.4)$ & 57 (16.3) & $36(10.3)$ & $\left|\begin{array}{l}115 \\
(32.9)\end{array}\right|$ & $60(17.1)$ & 350 & \multirow[t]{2}{*}{$\begin{array}{l}37.360 \\
0.001\end{array}$} \\
\hline & Rural & $117(33.4)$ & 87 (24.9) & 47 (13.4) & $\left|\begin{array}{l}57 \\
(16.3)\end{array}\right|$ & $42(12.0)$ & 350 & \\
\hline \multirow[t]{2}{*}{ I was ready when I got my first period } & Urban & $100(28.6)$ & $108(30.9)$ & $52(14.9)$ & $\left|\begin{array}{l}68 \\
(19.4)\end{array}\right|$ & $22(6.3)$ & 350 & \multirow[t]{2}{*}{$\begin{array}{l}15.115 \\
0.004\end{array}$} \\
\hline & Rural & 96 (27.4) & 85 (24.3) & $53(15.1)$ & $\left|\begin{array}{l}64 \\
(18.3)\end{array}\right|$ & $52(14.9)$ & 350 & \\
\hline
\end{tabular}


Mekle D. et al: Perception and practices pertaining to menstruation

\begin{tabular}{|c|c|c|c|c|c|c|c|c|}
\hline \multirow[t]{2}{*}{ I knew what to do when I got my first period } & Urban & $67(19.1)$ & $116(33.1)$ & $45(12.1)$ & $85(24.3)$ & $37(10.6)$ & 350 & \multirow{2}{*}{$\begin{array}{l}12.655 \\
0.13\end{array}$} \\
\hline & Rural & $97(27.7)$ & $103(29.4)$ & $40(11.4)$ & $62(17.7)$ & $48(13.7)$ & 350 & \\
\hline \multirow[t]{2}{*}{ I understood what was happening to my body when I got my first period } & Urban & $56(16.0)$ & $136(38.9)$ & 66 (18.9) & $59(16.9)$ & $33(9.4)$ & 350 & \multirow{2}{*}{$\begin{array}{l}15.456 \\
0.004\end{array}$} \\
\hline & Rural & $83(23.7)$ & $106(30.3)$ & $46(13.1)$ & 69 (19.7) & $46(13.1)$ & 350 & \\
\hline \multirow[t]{2}{*}{ It is safe to have pain killer for pains during period } & urban & $77(22.0)$ & $65(30.6)$ & $82(23.4)$ & $112(32.0)$ & $14(4.0)$ & 350 & \multirow{2}{*}{$\begin{array}{l}43.240 \\
0.001\end{array}$} \\
\hline & rural & $100(28.6)$ & $104(29.7)$ & $54(15.4)$ & $58(16.6)$ & $34(9.7)$ & 350 & \\
\hline \multirow[t]{2}{*}{ I miss my school during those days } & urban & $111(31.7)$ & $120(34.3)$ & 45 (12.9) & $51(14.6)$ & $23(6.6)$ & 350 & \multirow{2}{*}{$\begin{array}{l}3.801 \\
0.434\end{array}$} \\
\hline & rural & $101(28.9)$ & $111(31.7)$ & $42(12.0)$ & $65(18.6)$ & $31(8.9)$ & 350 & \\
\hline \multirow[t]{2}{*}{ I like to talk about periods with my friends } & urban & $47(13.4)$ & $68(19.4)$ & $75(21.4)$ & $126(36.0)$ & $34(9.7)$ & 350 & \multirow{2}{*}{$\begin{array}{l}109.711 \\
0.001\end{array}$} \\
\hline & rural & $129(36.9)$ & $113(32.3)$ & $20(5.7)$ & $55(15.7)$ & $33(9.4)$ & 350 & \\
\hline \multirow[t]{2}{*}{ I am embarrassed to ask questions about periods } & urban & $82(23.4)$ & $109(31.1)$ & 59 (16.9) & $75(21.4)$ & $25(7.1)$ & 350 & \multirow{2}{*}{$\begin{array}{l}11.182 \\
0.025\end{array}$} \\
\hline & Rural & 73 (20.9) & $145(41.4)$ & $38(10.9)$ & $65(18.6)$ & $29(8.3)$ & 350 & \\
\hline \multirow[t]{2}{*}{ I worry a lot that blood will stain my clothes } & Urban & $42(12.0)$ & $36(10.3)$ & $54(15.4)$ & $136(38.9)$ & $82(23.4)$ & 350 & \multirow{2}{*}{$\begin{array}{l}80.913 \\
0.001\end{array}$} \\
\hline & Rural & $96(27.4)$ & $96(27.4)$ & $40(11.4)$ & $68(19.4)$ & $50(14.3)$ & 350 & \\
\hline
\end{tabular}

\section{Discussion}

During the adolescent phase, the girls experience common menstruation-related problems and do not receive appropriate knowledge due to the lack of a proper health education program in schools. Moreover, the topic of menstruation is associated with taboo, and traditional Indian society discourages open discussion on these issues [10].

The present study showed that the age of attaining menarche ranged from $11-16$ years with the maximum number of girls were between 12-14 years. In a similar study done in Rural West Bengal by Dasgupta et al, the age of attaining menarche ranged from 14 to 17 years, maximum (76.25\%) number of girls being between 14 and 15 years of age group [5].

In the present study, only $17.1 \%$ in Urban and $12 \%$ of girls in rural settings had prior knowledge of menstruation before attaining menarche. The percentage is low in the present study as compared to previous findings of the study done in Rural Gujarat by Dasgupta et al in which the author showed $62.7 \%$ of the girls had prior knowledge of menstruation [5].

Literacy regarding menstruation among mothers in the present study is similar to the findings of Unni et al who observed that mothers who are the most common source of information to these girls were poorly literates and hence the quality of knowledge imparted might have been poor [11]. This is in agreement with the present study as the majority of the mothers from rural settings had limited school education as compared to urban areas.
This reiterates the fact that mothers of adolescents should be an integral part of all programs on adolescent health and especially on menstrual hygiene [12].

Another hospital-based study on 100 adolescent girls also showed that maternal education was significantly associated with girl's practice of using the commercially available sanitary pad, though no significant association was found with cleaning practices of the external genitalia and girl's mental preparedness for menstruation [13].

Hygiene related practices of women during menstruation are of considerable importance as it affects health by increasing vulnerability to infection especially the infections of urinary tract and perineum. In the present study majority of girls from urban areas used sanitary pads (96.3\%) as compared to rural settings (69.4\%). The use of sanitary pad was higher which was probably due to the fact that the availability was high in urban areas and also due to the influence of television which has increased their awareness regarding the availability and use of sanitary pads. The use of soap and water to clean their private parts was higher in urban areas $(63.7 \%)$ as compared to girls from the rural setting (48.9\%). A similar study by Dasgupta et al from West Bengal showed that $97.5 \%$ of the girls used both soap and water to clean their private parts [5]. This shows that personal hygiene practices were unsatisfactory in the present study population. A similar study by Thakre et al, Nagpur reported that girls used old clothes in $45.74 \%$ of the subjects [7]. Various restrictions imposed on menstruating adolescent girls may be due to sociocultural beliefs that during menstruation females are in a state of uncleanliness. 
Our findings are supported by Gupta et al in which the authors stressed traditional beliefs regarding menstruation still persist and menstrual hygiene among the adolescents was found to be unsatisfactory. It highlights the need for targeted interventions to raise awareness and provision of family health education package to all girls [14].

The strength of the present study is the large sample size and inclusion of both the urban and rural populations. The limitation being the exclusion of late adolescent as by that age they are no longer a school going students.

\section{Conclusion}

The menstruation is found to be associated with social stigma in both rural as well as the urban settings. There is a need to disseminate healthy menstrual knowledge at all levels and promote good menstrual hygienic practices.

\section{What does the study add to the existing knowledge?}

Adolescents must be recognized as a priority target group. There are different types of misconceptions, myths, restriction, and lack of menstruation-related knowledge. There is a need for special policies and programs to address the problems of adolescents to prevent disease and promote good health in them. Education regarding reproductive health with more focus on menstrual hygiene should be made part of the school curriculum.

\section{Authors Contribution}

Dr. J. Dixit: Topic selection, Study design.

Dr. Anju Kapoor: Manuscript preparation, Topic selection. Questionnaire preparation.

Dr. Dinesh Mekle: Questionnaire preparation, Study design, Data analysis.

Dr. Richa Rathore: Data collection, Entry of data, and Analysis.

\section{Reference}

01. Ghai OP, Paul VK, Bagga A. Essential Pediatrics, 7th ed, New Delhi. CBS Publishers and Distributors Pvt Ltd. 2009. [Crossref][PubMed][Google Scholar]
02. Paul D, Patnaik R, Gopalakrishnan S. Improvement in knowledge and practices of adolescent girls on reproductive health with focus on hygiene during menstruation in five years. Health and Population-Perspectives and Issues. 2014;37(1 and 2)1-4. [Crossref][PubMed][Google Scholar]

03. Freeman EW. Premenstrual syndrome and premenstrual dysphoric disorder- definitions and diagnosis. Psychoneuroendocrinology. 2003;28(3)25-37. doi: [Article][Crossref][PubMed] [Google Scholar]

04. Garg S, Anand T. Menstruation related myths in India- strategies for combating it. J Family Med Prim Care. 2015;4(2)184-186. doi: 10.4103\%2F22494863.154627 [Crossref][PubMed][Google Scholar]

05. Dasgupta A, Sarkar M. Menstrual hygiene- how hygienic is the adolescent girl. Indian J Community Med. 2008;33(2)77-80. Available from: [Article] [Crossref][PubMed][Google Scholar]

06. Paria B, Bhattacharyya A, Das S. A comparative study on menstrual hygiene among urban and rural adolescent girls of West Bengal. J Family Med Prim Care. 2014;3(4)413-417. Available from: [Article] [Crossref][PubMed][Google Scholar]

07. Thakre SB, Thakre SS, Reddy M, Rathi N, Pathak $\mathrm{K}$, Ughade S. Menstrual hygiene- Knowledge and practice among adolescent schoolgirls of Saoner, Nagpur district. J Clin Diagn Res. 2011;5(5)10271033. [Crossref][PubMed][Google Scholar]

08. Poureslami, Oasti-Ashtiani F. Attitude of female adolescents about dysmenorrhoea and menstrual hygiene $\mathrm{s}$ in Tehran suburbs. Arch Indian Med. 2002;5;377-396. [Crossref][PubMed][Google Scholar]

09. World Health Organization, Regional Office for South-East Asia. Health situation in the South-East Asia Region, 2001-2007. WHO Regional Office for South-East Asia. 2008. Available at [Article] [Crossref][PubMed][Google Scholar]

10. Singh MM, Devi R, Gupta SS. Awareness and health seeking behaviour of rural adolescent schoolgirls on menstrual and reproductive health problems. Indian J Med Sci. 1999;53(10)439-443. [Crossref][PubMed][Google Scholar]

11. Drakshayani KD, Venkata PR. A study on menstrual hygiene among rural adolescent girls. Indian J Med Sci. 1994;48(6)139-143. [Crossref] [PubMed][Google Scholar] 
12. Unni JC. Adolescent attitudes and relevance to family life education programs. Indian Pediatr. 2010;47(2)176-179. [Crossref][PubMed][Google Scholar]

13. Kapoor A, Khari S. Knowledge, Attitude and Socio-cultural Beliefs of Adolescent Girls Towards Menstruation. J Nepal Paediatr Soc. 2016;36(1)4249. doi: 10.3126/jnps.v36i1.14386 [Crossref] [PubMed][Google Scholar]
14. Gupta P, Gupta J, Singhal G, Meharda B. Knowledge and practices pertaining to menstruation among the school going adolescent girls of UHTC/RHTC area of Government Medical College, Kota, Rajasthan. Int J Community Med Public Health. 2018;5(2)652-656. doi: 10.18203/23946040.ijcmph20180245 [Crossref][PubMed][Google Scholar] 